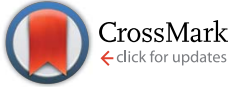

Cite this: RSC Adv., 2016, 6, 70099
Received 2nd June 2016 Accepted 12th July 2016

DOI: $10.1039 / c 6 r a 14356 c$

www.rsc.org/advances

\section{Synthesis of 4-thio-5-(2"-thienyl)uridine and cytotoxicity activity against colon cancer cells in vitro†}

\begin{abstract}
Xiaohui Zhang, ${ }^{a}$ Depeng Li, ${ }^{a}$ Jianzhong Qin, ${ }^{b}$ Yaozhong $\mathrm{Xu}^{\star \mathrm{c}}$ and Kedong Ma*a
A novel anti-tumor agent 4-thio-5-(2"-thienyl)uridine (6) was synthesized and the in vitro cytotoxicity activity against mice colon cancer cells (MC-38) and human colon cancer cells (HT-29) was evaluated by MTT assay. The results showed that the novel compound had antiproliferative activity toward MC-38 and HT-29 cells in a dose-dependent manner. The cell cycle analysis by flow cytometry indicated that compound 6 exerted in tumor cell proliferation inhibition by arresting HT-29 cells in the G2/M phase. In addition, cell death detected by propidium iodide staining showed that compound 6 efficiently induced cell apoptosis in a concentration-dependent manner. Moreover, the sensitivity of human fibroblast cells to compound 6 was far lower than that of tumor cells, suggesting the specific anti-tumor effect of 4thio-5-(2" -thienyl)uridine. Taken together, novel compound 6 effectively inhibits colon cancer cell proliferation, and hence would have potential value in clinical application as an antitumor agent.
\end{abstract}

\section{Introduction}

The flow of genetic information is directed by nucleic acids (DNA and RNA). The base analogues structurally similar to the four canonical bases can be incorporated into DNA, which alter their properties and facilitate basic studies of DNA-related processes such as its interaction with proteins, replication and transcription. ${ }^{1,2}$ Structural modification of nucleosides is biologically meaningful, and has led to the discovery of a variety of new therapeutic agents, which includes antiviral and anticancer agents. Pyrimidines and fused pyrimidines, being an integral part of DNA and RNA have considerable chemical and pharmacological importance. Thio-pyrimidine compounds in which an oxygen atom in the base is replaced by sulfur have been reported to show improved anti-cancer activity and immune enhancement..$^{3-7}$

Thiophene and its derivatives as important sulfurcontaining five-member heterocyclic compounds have various biological and pharmacological properties in terms of antimicrobial and antitumor activities. ${ }^{8-10} \mathrm{As}$ a rich electronic aromatic ring compound, the charge density of thiophene is greater than that of benzene ring, and thus, it is easy for thiophene to occur

${ }^{a}$ College of Environment and Chemical Engineering, Dalian University, Dalian 116622, PR China. E-mail: makedongdl@yahoo.co.jp; Fax: +86-411-87402440; Tel: +86-41187402440

${ }^{b}$ School of Life Science and Biotechnology, Dalian University, Dalian 116622, China ${ }^{\circ}$ Department of Life, Health and Chemical Sciences, The Open University, Walton Hall, Milton Keynes, MK7 6AA, UK. E-mail: y.z.xu@open.ac.uk

$\dagger$ Electronic supplementary information (ESI) available. CCDC 1479957. For ESI and crystallographic data in CIF or other electronic format see DOI: 10.1039/c6ra14356c the $\pi-\pi$ interactions. Moreover, the sulfur atom in thiophene is certain nucleophilic and easy to interact with electrophilic receptors or form metal or metal ion. From the viewpoint of reducing the drug side effects, enhancing the drug targeting and improving the pharmacokinetic properties of drugs and the corresponding therapeutic index, new compound with the characteristics of both thiophene and thio-pyrimidine are certainly with explore as attractive antitumor agent. ${ }^{11,12}$

Colon cancer is a kind of digestive tract malignant tumor, commonly occurring at the junction of the rectum and sigmoid colon. The incidence of colon cancer begins to rise at age 40 and peaks at age 60 to 75 , and the main life-style related cause is high-fat diet and inadequate cellulose intake. Colon cancer ranks third among the leading causes of cancer-associated death after lung and prostate cancer for men and after lung and breast cancer for women. ${ }^{13}$ In recent years, there is an upward trend in China as the improvement of people's living standard and changes in diet. Accordingly, the development of novel chemotherapeutic agents is an urgent issue.

In this study, a novel 4-thio-5-(2"-thienyl)uridine (6) compound was synthesized by introducing a thiophene to uridine by a series of reaction (Scheme 1). The cytotoxicity of compound was evaluated by in vitro administering to mice colon cancer cells line (MC-38) and human colon cancer cells line (HT-29) by MTT assay, respectively. Compound 6 was found to have antiproliferative activity against colon cancer cells. Flow cytometry examination revealed that compound 6 inhibited cell growth through cell cycle arrest at G2/M phase. Combined with no cytotoxic and apoptotic effect on human fibroblast cells, 4-thio-5-(2"-thienyl)uridine (6) have potential clinical applications. 

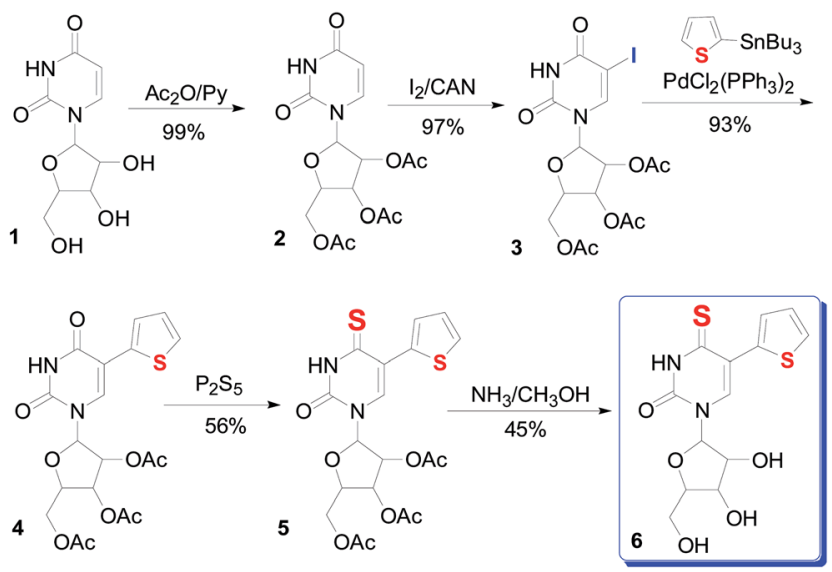

Scheme 1 Synthetic route of 4-thio-5-(2" -thienyl)uridine.

\section{Experimental section}

\subsection{Apparatus and materials}

Reagents were obtained from commercial suppliers and were used without further purification. Melting point was determined on a XR-4-type micro-melting point detector, and was uncorrected. The compounds synthesized were purified by column chromatography using silica gel (200-300 mesh) except for recrystallization and thin-layer chromatography (TLC) using silica gel 60 F254 plates (250 mm; Qingdao Ocean Chemical Company, China). IR spectra were recorded using a Nicolet 550 Spectrophotometer (4000-400 $\mathrm{cm}^{-1}$ ) with a crystalline sample spread on $\mathrm{KBr}$ pellets. UV spectra were recorded using UV-vis spectrophotometer (JASCO, Japan); ${ }^{1} \mathrm{H}$ NMR and ${ }^{13} \mathrm{C}$ NMR spectra were obtained by a $500 \mathrm{MHz}$ Bruker AV-400 spectrometer with TMS as an internal standard. The mass spectrum was obtained on Hewlett-Packard 1100 LC/MSD spectrometer.

\subsection{Crystal structure}

The crystallographic data for 4-thio-5-(2" -thienyl)uridine were summarized in Table 1. X-ray diffraction data were collected at 120 K using a Bruker Nonius Kappa CCD diffractometer mounted at the window of a Bruker FR591 rotating anode (Mo $\mathrm{K} \alpha, \lambda=0.71073 \AA$ ) and equipped with Bruker APEX II detector and Oxford Cryosystems Cryostream device. ORTEP views of 4thio-5-(2"-thienyl)uridine were given in Fig. S4. $\uparrow$ The structure was solved by direct methods using SHELXS97.22 The crystal structure has been deposited in Cambridge Structural Database: CCDC depository number 1479957.

\subsection{Synthesis and characterization of 4-thio-5-(2"-thienyl) uridine and its intermediates (1-6)}

2.3.1. Acetyl protected uridine (2). The nucleoside (uridine, 1) $(4.09 \mathrm{mmol})$ was dissolved in anhydrous pyridine $(12 \mathrm{~mL})$, and then dry acetic anhydride $(2.75 \mathrm{~mL}, 29 \mathrm{mmol})$ was added under ice bath condition. The reaction was monitored by thin layer chromatography. The reaction material point disappeared after about $5 \mathrm{~h}$. The solvent was evaporated under reduced pressure condition, and the residue was recrystallized from
Table 1 Summary of crystallographic data for 4-thio-5-(2" -thienyl) uridine

$\begin{array}{ll}\text { Compound } & 4 \text {-thio-5-(2" } 2^{\prime \prime} \text { thienyl)uridine } \\ \text { Empirical formula } & \mathrm{C}_{13} \mathrm{H}_{15} \mathrm{~N}_{2} \mathrm{O}_{5.50} \mathrm{~S}_{2} \\ \text { Formula weight } & 351.39 \\ \text { Crystal system } & \text { Monoclinic } \\ \text { Space group } & P 2_{1} \\ \text { Unit cell dimensions } & a=14.5426(10) \AA, \alpha=90^{\circ} \\ & b=7.8358(5) \AA, \beta=98.267(2)^{\circ} \\ & c=50.555(4) \AA, \gamma=90^{\circ} \\ \text { Volume } & 5701.4(7) \AA^{3} \\ Z & 16 \\ \text { Density (calculated) } & 1.637 \mathrm{mg} \mathrm{m}^{-3} \\ \text { Absorption coefficient } & 0.404 \mathrm{~mm}^{-1} \\ F(000) & 2928 \\ \text { Crystal } & \mathrm{Cut} \mathrm{blade;} \mathrm{yellow} \\ \text { Crystal size } & 0.170 \times 0.090 \times 0.030 \mathrm{~mm}^{3} \\ \theta \text { range for data collection } & 2.306-27.512^{\circ} \\ \text { Index ranges } & -18 \leq h \leq 18,-10 \leq k \leq 10, \\ & -64 \leq l \leq 65 \\ \text { Reflections collected } & 69998 \\ \text { Independent reflections } & 25854\left[R_{\mathrm{int}}=0.0589\right] \\ \text { Goodness-of-fit on } F^{2} & 1.031 \\ \text { Final } R \text { indices }\left[F^{2}>2 \sigma\left(F^{2}\right)\right] & R_{1}=0.0469, \mathrm{w} R_{2}=0.1208 \\ R \text { indices (all data) } & R_{1}=0.0562, \mathrm{w} R_{2}=0.1265 \\ \text { Absolute structure parameter } & 0.02(3) \\ \text { Extinction coefficient } & \mathrm{n} / \mathrm{a} \\ \text { Largest diff. peak and hole } & 0.775 \text { and }-0.402 \mathrm{e} \AA^{-3} \\ & \end{array}$

ethanol to give white block crystal of acetyl protected pyrimidine (2). Yield 99\%; mp: $126-129{ }^{\circ} \mathrm{C}$ (lit. mp: $\left.127-129{ }^{\circ} \mathrm{C}\right) \cdot{ }^{23}{ }^{1} \mathrm{H}$ NMR (400 MHz, $\mathrm{CDCl}_{3}$ ) $\delta: 9.48$ (brs, $\left.1 \mathrm{H}, \mathrm{NH}\right), 7.41$ (d, $J=8.16$ $\mathrm{Hz}, 1 \mathrm{H}, 6 \mathrm{H}), 6.05$ (d, $\left.J=4.76 \mathrm{~Hz}, 1 \mathrm{H}, 1^{\prime}-\mathrm{H}\right), 5.80$ (d, $J=8.16 \mathrm{~Hz}$, $1 \mathrm{H}, 5 \mathrm{H}), 5.34-5.35\left(\mathrm{~m}, 2 \mathrm{H}, 2^{\prime}-\mathrm{H}, 3^{\prime}-\mathrm{H}\right), 4.35-4.36\left(\mathrm{~m}, 3 \mathrm{H}, 4^{\prime}-\mathrm{H}, 5^{\prime}-\right.$ $\mathrm{H})$, 2.11-2.15 (m, 9H, $\left.3 \times-\mathrm{OC}=\mathrm{OCH}_{3}\right)$; IR (film) $/ \mathrm{cm}^{-1}: 1755$, $1720(\mathrm{C}=\mathrm{O}), 1694$ (amide $\mathrm{C}=\mathrm{O}), 1630(\mathrm{C}=\mathrm{C})$.

2.3.2. 5-Iodo-acetyl protected pyrimidine (3). A mixture of acetyl protected nucleosides (2) (0.5 mmol), iodine (76 $\mathrm{mg}, 0.3$ $\mathrm{mmol})$, ceric ammonium nitrate (CAN) $(137 \mathrm{mg}, 0.25 \mathrm{mmol})$ and MeCN ( $8 \mathrm{~mL}$ ) was stirred at $80{ }^{\circ} \mathrm{C}$ for $1 \mathrm{~h}$. The reaction progress was monitored by TLC (solvent $\mathrm{CH}_{3} \mathrm{Cl} /$ acetone $4: 1$ ). The solvent was evaporated and the residue was partitioned in a cold mixture of EtOAc $(20 \mathrm{~mL})$, saturated $\mathrm{NaCl} / \mathrm{H}_{2} \mathrm{O}(10 \mathrm{~mL})$, $\mathrm{NaHSO}_{3} / \mathrm{H}_{2} \mathrm{O}(5 \mathrm{~mL})$. Then, the aqueous layer was extracted with EtOAc $(10 \mathrm{~mL} \times 2)$. The organic layer was collected and washed carefully using $5 \%$ cold $\mathrm{NaHSO}_{3} / \mathrm{H}_{2} \mathrm{O}(5 \mathrm{~mL})$, then followed by saturated $\mathrm{NaCl} / \mathrm{H}_{2} \mathrm{O}(15 \mathrm{~mL})$ and $\mathrm{H}_{2} \mathrm{O}(15 \mathrm{~mL} \times 2)$, finally dried by anhydrous magnesium sulfate to remove water. The crude 5iodo products were purified by column chromatography or recrystallized to give the target compound (3) with the yield around 97\%, mp: $175-176{ }^{\circ} \mathrm{C}$ (lit. mp: $177-178{ }^{\circ} \mathrm{C}$ ). ${ }^{1} \mathrm{H}$ NMR (400 MHz, DMSO-d $)_{6}$ ) 11.83 (brs, 1H, NH), 8.18 (s, 1H, 6-H), $5.88\left(\mathrm{~d}, J=4.0 \mathrm{~Hz}, 1 \mathrm{H}, 1^{\prime}-\mathrm{H}\right), 5.47$ (dd, $\left.J=8.0 \mathrm{~Hz}, 1 \mathrm{H}, 2^{\prime}-\mathrm{H}\right)$, 5.33-5.35 (m, 1H, 3'-H), 4.31-4.36 (m, 1H, 4'-H), 4.21-4.27 (m, $\left.2 \mathrm{H}, 5^{\prime}-\mathrm{H}\right), 2.06,2.07,2.08$ ( $\left.3 \mathrm{~s}, 3 \mathrm{H}, 3 \mathrm{H}, 3 \mathrm{H}, \mathrm{OAc}\right)$; UV (in $\mathrm{CH}_{3} \mathrm{CN}$ ): $\lambda_{\min }=257.0 \mathrm{~nm}, 226.5 \mathrm{~nm}$.

2.3.3. 5-(2" -Thienyl)-acetyl-protected nucleoside (4). Bis(triphenylphosphine) palladium(II) chloride (0.016 g, 0.023 $\mathrm{mmol})$ and tributyl-thiophene-2-yl-stannane $(3.42 \mathrm{mmol})$ was 
added to the solution of 5-iodo-acetyl protected nucleosides (3) $(1.14 \mathrm{mmol})$ which dissolved in anhydrous and peroxide-free 1,4-dioxane $(30 \mathrm{~mL})$ under argon atmosphere, the mixture was heated at $90{ }^{\circ} \mathrm{C}$ and refluxing for $3 \mathrm{~h}$ (TLC tracking reaction). After cooling down, the black solid was filtered through celite to remove the solvent. Silica gel chromatography $\left(10 \% \mathrm{CH}_{3} \mathrm{OH} /\right.$ $\mathrm{CH}_{2} \mathrm{C}_{2}$ ) yielded white solid compound with yield of around 93\%, namely 5-(2" -thienyl)-acetyl protected nucleoside (4). Mp: 178-181 ${ }^{\circ} \mathrm{C} .{ }^{1} \mathrm{H}$ NMR (400 MHz, DMSO-d 6 ) $\delta: 11.83$ (brs, $1 \mathrm{H}$, $\mathrm{NH}), 8.17$ (s, 1H, 6-H), 7.46-7.50 (m, 2H, 5" - H, 3"-H), 7.07 (m, $\left.1 \mathrm{H}, 4^{\prime \prime}-\mathrm{H}\right), 5.94-5.95\left(\mathrm{~d}, 1 \mathrm{H}, J=4.0 \mathrm{~Hz}, 1^{\prime}-\mathrm{H}\right), 5.57-5.60(\mathrm{t}, 1 \mathrm{H}, J$ $\left.=12.0 \mathrm{~Hz}, 3^{\prime}-\mathrm{H}\right), 5.34-5.39\left(\mathrm{~m}, 1 \mathrm{H}, 2^{\prime}-\mathrm{H}\right), 4.25-4.36\left(\mathrm{~m}, 3 \mathrm{H}, 4^{\prime}-\mathrm{H}\right.$, $\left.5^{\prime}-\mathrm{H}\right), 2.04-2.06\left(\mathrm{~m}, 9 \mathrm{H}, \mathrm{CH}_{3}\right) ;{ }^{13} \mathrm{C}$ NMR (DMSO-d 6 , $\left.500 \mathrm{MHz}\right) \delta$ : 170.49, 169.83, $169.79(3 \times-\mathrm{C}=\mathrm{O}), 137.27$ (C-4), $126.92(\mathrm{C}-2)$, $126.71\left(\mathrm{C}-2^{\prime \prime}\right), 124.02\left(\mathrm{C}-5^{\prime \prime}\right), 109.51$ (C-6), $89.28\left(\mathrm{C}-4^{\prime \prime}\right), 79.75$ (C-3"), 79.64 (C-5), $72.51\left(\mathrm{C}-4^{\prime}\right), 72.44\left(\mathrm{C}-1^{\prime}\right), 70.07\left(\mathrm{C}-3^{\prime}\right), 69.95$ $\left({\mathrm{C}-5^{\prime}}^{\prime}\right), 63.44\left(\mathrm{C}-2^{\prime}\right), 20.97,20.77,20.71\left(3 \times-\mathrm{CH}_{3}\right)$; HRMS: [M + $\mathrm{Na}]^{+}$475.0790, calculated for $\mathrm{C}_{19} \mathrm{H}_{20} \mathrm{~N}_{2} \mathrm{O}_{9} \mathrm{SNa}$; found 475.0793. UV-vis (in $\mathrm{CH}_{3} \mathrm{CN}$ ): $\lambda_{\max } / \mathrm{nm}: 262.0,304.0$. IR (film) $/ \mathrm{cm}^{-1}: 1748.0$ $\left(\mathrm{C}=\mathrm{OCH}_{3}\right), 1717.5(\mathrm{C}=\mathrm{O}), 1459.4,1374.3(\mathrm{NH}), 1571.3,1414.0$, $1299.8(\mathrm{C}=\mathrm{C}), 1627.47(\mathrm{C} 5=\mathrm{C} 6)$.

2.3.4. 4-Thio-5-(2" -thienyl)-acetyl protected nucleoside (5). 5-(2"-Thienyl)-acetyl protected nucleoside (4) (2.32 mmol) were dissolved in peroxide-free 1,4-dioxane $(50 \mathrm{~mL})$, then $\mathrm{P}_{2} \mathrm{~S}_{5}(1.0$ $\mathrm{g}, 4.50 \mathrm{mmol}$ ) was added. The mixture was refluxed for 3-4 $\mathrm{h}$ when TLC analysis showed complete disappearance of the starting material. The solvent was removed under reduced pressure and the residue was treated with $\mathrm{CH}_{2} \mathrm{Cl}_{2}$ for several times. The residue was separated on a silica gel column, eluting with petroleum : ethyl acetate $(3: 2, \mathrm{v} / \mathrm{v})$ to give the title compound (5) at yield of 56\%. Mp: $171-173{ }^{\circ} \mathrm{C} .{ }^{1} \mathrm{H}$ NMR $(400$ MHz, DMSO-d 6 ) $\delta: 13.07$ (brs, $1 \mathrm{H}, \mathrm{NH}), 8.05$ (s, 1H, 6-H), 7.57$7.58\left(\mathrm{~d}, 1 \mathrm{H}, J=4.0 \mathrm{~Hz}, 5^{\prime \prime}-\mathrm{H}\right), 7.29-7.30\left(\mathrm{~d}, 1 \mathrm{H}, J=4.0 \mathrm{~Hz}, 3^{\prime \prime}-\right.$ $\mathrm{H}), 7.06-7.08\left(\mathrm{t}, 1 \mathrm{H}, J=4.0 \mathrm{~Hz}, 3^{\prime}-\mathrm{H}\right), 5.35-5.41\left(\mathrm{~m}, 1 \mathrm{H}, 2^{\prime}-\mathrm{H}\right)$, 4.25-4.36 (m, 3H, 4'-H, 5'-H), $2.07\left(\mathrm{~m}, 9 \mathrm{H}, \mathrm{CH}_{3}\right) ;{ }^{13} \mathrm{C}$ NMR $\left(\right.$ DMSO-d $\left._{6}, 500 \mathrm{MHz}\right) \delta: 188.58$ (C-4), 170.43, 169.78, 169.75 $(3 \times-\mathrm{C}=\mathrm{O}), 147.07(\mathrm{C}-2), 136.74\left(\mathrm{C}-2^{\prime \prime}\right), 136.41\left(\mathrm{C}-5^{\prime \prime}\right), 127.11$ (C-6), $126.34\left(\mathrm{C}-4^{\prime \prime}\right), 117.96\left(\mathrm{C}-3^{\prime \prime}\right), 89.96(\mathrm{C}-5), 79.97\left(\mathrm{C}-4^{\prime}\right)$, $72.72\left(\mathrm{C}-1^{\prime}\right), 69.92\left(\mathrm{C}-3^{\prime}\right), 66.83\left(\mathrm{C}-5^{\prime}\right), 63.22\left(\mathrm{C}-2^{\prime}\right), 20.81,20.77$, $20.74\left(3 \times-\mathrm{CH}_{3}\right)$; HRMS: $[\mathrm{M}+\mathrm{H}]^{+} 467.0741$, calculated for $\mathrm{C}_{19} \mathrm{H}_{20} \mathrm{~N}_{2} \mathrm{O}_{8} \mathrm{~S}_{2}$; found 469.0727. UV-vis (in $\mathrm{CH}_{3} \mathrm{CN}$ ): $\lambda_{\max } / \mathrm{nm}$ : 239, 285, 348. IR (film) $/ \mathrm{cm}^{-1}$ : $1747.5\left(\mathrm{C}=\mathrm{OCH}_{3}\right), 1715.6(\mathrm{C}=$ O), 1451.7, $1371.3(\mathrm{NH}), 1522.7,1227.5,1427.31(\mathrm{C}=\mathrm{C}), 1610$ $(\mathrm{C} 5=\mathrm{C} 6), 1108(\mathrm{C}=\mathrm{S})$.

2.3.5. 4-Thio-5-(2"-thienyl)-nucleoside (6). 4-Thio-5-(2" thienyl)-acetyl protected nucleoside (5) (2.14 $\mathrm{mmol})$ were suspended in absolute $\mathrm{MeOH}(60 \mathrm{~mL}, 1.5 \mathrm{mmol})$ and saturated with dry ammonia gas. The mixture was stirred at room temperature for $4.5 \mathrm{~h}$. The resulting solution was evaporated under reduced pressure at $35{ }^{\circ} \mathrm{C}$ and the residue was purified on a silica gel column packed in $\left(\mathrm{CH}_{2} \mathrm{C}_{12}: \mathrm{MeOH} 9: 1, \mathrm{v} / \mathrm{v}\right)$ and provide a solid product at yields of $45 \%$, namely 4 -thio-5-(2" thienyl) nucleoside (6). Mp: $185-187{ }^{\circ} \mathrm{C} .{ }^{1} \mathrm{H}$ NMR $(400 \mathrm{MHz}$, DMSO-d $_{6}$ ) $\delta: 12.89$ (brs, $\left.1 \mathrm{H}, \mathrm{NH}\right), 8.51$ (s, 1H, 6-H), 7.47-7.48 $\left(\mathrm{d}, 1 \mathrm{H}, J=4.0 \mathrm{~Hz}, 5^{\prime \prime}-\mathrm{H}\right), 7.27-7.28\left(\mathrm{~m}, 1 \mathrm{H}, 3^{\prime \prime}-\mathrm{H}\right), 6.98-7.00(\mathrm{~m}$, $\left.1 \mathrm{H}, 4^{\prime \prime}-\mathrm{H}\right), 5.75-5.76\left(\mathrm{~d}, 1 \mathrm{H}, J=4.0 \mathrm{~Hz}, 1^{\prime}-\mathrm{H}\right), 5.50-5.51(\mathrm{~d}, 1 \mathrm{H}, J$ $=4.0 \mathrm{~Hz}, \mathrm{OH}), 5.30-5.32(\mathrm{t}, 1 \mathrm{H}, J=4.0 \mathrm{~Hz}, \mathrm{OH}), 5.06-5.07$ (d, $\left.1 \mathrm{H}, J=4.0 \mathrm{~Hz}, 5^{\prime}-\mathrm{OH}\right), 4.10-4.14\left(\mathrm{~m}, 1 \mathrm{H}, 3^{\prime}-\mathrm{H}\right), 4.00-4.04$ (m, 1H, 2'-H), 3.89-3.90 (m, 1H, 4'-H), 3.56-3.72 (m, 2H, 5'-H); ${ }^{13} \mathrm{C}$ NMR (DMSO-d $6,500 \mathrm{MHz}$ ) $\delta: 187.52$ (C-4), 172.04 (C-2), $147.36\left(\mathrm{C}-2^{\prime \prime}\right), 136.91\left(\mathrm{C}-5^{\prime \prime}\right), 135.73(\mathrm{C}-6), 127.09\left(\mathrm{C}-4^{\prime \prime}\right)$, $126.23\left(\mathrm{C}-3^{\prime \prime}\right), 117.61(\mathrm{C}-5), 89.80\left(\mathrm{C}-4^{\prime}\right), 85.20\left(\mathrm{C}-1^{\prime}\right), 74.87$ (C3'), 69.57 (C-5'), 60.32 (C-2'), HRMS: $[\mathrm{M}+\mathrm{Na}]^{+}$365.0244, calculated for $\mathrm{C}_{13} \mathrm{H}_{14} \mathrm{~N}_{2} \mathrm{O}_{5} \mathrm{~S}_{2} \mathrm{Na}$; found 365.0249. UV-vis (in $\left.\mathrm{CH}_{3} \mathrm{CN}\right): \lambda_{\max } / \mathrm{nm}: 239,287,356$. IR (film) $/ \mathrm{cm}^{-1}: 3344.3(-\mathrm{OH})$, $1699.7(\mathrm{C}=\mathrm{O}), 1519.0,1280.8(\mathrm{C}=\mathrm{C}), 1600.2(\mathrm{C} 5=\mathrm{C} 6), 1122.6$ $(\mathrm{C}=\mathrm{S})$.

\subsection{Toxicity test on colon cancer cells}

The MTT colorimetric method and flow cytometry were employed to analyze the anti-tumor activity of 4-thio-5-(2"thienyl)uridine on mice colon cancer cell line MC-38 and human colon cancer cell line HT-29, which were purchased from the American Type Culture Collection.

2.4.1. Cell antiproliferative activity assay. The proliferation inhibitory activities of the synthesized target compounds was evaluated using mouse and human colon tumor cell lines (MC38 and HT-29) by the MTT method in vitro. MC-38 and HT-29 cells were cultured in DMEM and RPMI1640 medium, 10\% fetal calf serum, $100 \mu \mathrm{g} \mathrm{mL} \mathrm{m}^{-1}$ penicillin, and $100 \mu \mathrm{g} \mathrm{mL}$ streptomycin at $37{ }^{\circ} \mathrm{C}$ under $5 \% \mathrm{CO}_{2}$, respectively. Then the cells were seed into 96-well plate at $1 \times 10^{4}$ cells per well and coincubated with 4-thio-5-(2" -thienyl)uridine under different concentrations (final concentration: $100 \mu \mathrm{M}, 200 \mu \mathrm{M}, 300 \mu \mathrm{M}$, $400 \mu \mathrm{M}$ and $500 \mu \mathrm{M}$ ) for $24 \mathrm{~h}$, respectively. At the end of this time interval, $20 \mu \mathrm{L}$ (5 mg mL $\left.{ }^{-1}\right)$ MTT (3-(4,5 dimethylthiazol-2yl)-2,5-diphenyltetrazolium bromide) was added to each well, and after incubation at $37{ }^{\circ} \mathrm{C}$ for $4 \mathrm{~h}$ the MTT solution was removed and $100 \mu \mathrm{L}$ of dimethylsulfoxide (DMSO) was added to dissolve the crystals. The absorbance of each well was measured at $570 \mathrm{~nm}$.

2.4.2. Cell cycle distribution and apoptosis analysis by flow cytometry detection. Cell cycle distribution and apoptosis analysis was conducted according to the reported procedure. ${ }^{24}$ Briefly, the HT-29 cells were inoculated into a 6-well cell culture plate at $5 \times 105$ cells per well and cultured overnight. Then, 2 $\mathrm{mL}$ of the culture medium containing different concentrations of 4-thio-5-(2" -thienyl)uridine were added to each well respectively and co-incubated for another 48 hours. Afterwards, the cells floating in the supernatant were combined with the adherent fraction, washed with phosphate buffered saline (PBS) thrice, fixed with cool ethanol, treated with RNase, and then stained with propidium iodide $\left(50 \mu \mathrm{g} \mathrm{mL}^{-1}\right)$ at $37^{\circ} \mathrm{C}$ in a dark environment. The samples were immediately analyzed by flow cytometry.

\subsection{Statistical analysis}

Data were presented as mean \pm SD of three independent experiments. One-way analysis of variance (ANOVA) was performed on the data to assess the impact of the variables on the results. SPSS 13.0 statistical software (SPSS Inc., Chicago, USA) was used for the statistical analysis of all data. A $p$ value of $\leq 0.05$ was considered to be statistically significant. 


\section{Results and discussion}

\subsection{Chemistry synthesis}

3.1.1. Synthetic route to 4-thio-5-( $2^{\prime \prime}$-thienyl)uridine. The synthetic route to the target 4 -thio-5-(2"-thienyl)uridine was depicted in Scheme 1. The starting uridine 1 was first acetylated at its $2^{\prime}-, 3^{\prime}$ - and $5^{\prime}$-positions to produce the acetylated compound 2 . The compound 3, an important intermediate was easily synthesized via iodine and CAN (ceric ammonium nitrate) in MeCN. Then, the synthesis of compound $\mathbf{4}$ was carried out through palladium catalyzed stille cross coupling reaction to produce the thien-conjugated uridine 4 with a yield of over $90 \% .{ }^{14-17}$ Next, compound 5 was prepared according to the reported procedure with some modification. ${ }^{18,19}$ Finally the protecting groups were removed with ammonia in methanol to produce 4-thio-5-(2"-thienyl)uridine 6 with good yields. After the target compound was successfully prepared, structural characteristics of the compound were examined on UV, MS and NMR spectroscopies, the results were shown in ESI (Fig. S1-S3†).

\subsection{Cytotoxicity activities}

3.2.1. Anti-proliferative activity of compound 6 against mouse colon cancer cell MC-38 in vitro. The cytotoxic effect of the prepared compound was evaluated against mouse colon cancer cell MC-38. The MC-38 cell line was treated with compound 6 (final concentrations: 100, 200, 300, 400, $500 \mu \mathrm{M}$ ) for $48 \mathrm{~h}$, and the viable cells were measured by a MTT assay. As shown in Fig. 1, the cell growth inhibition was observed under different concentration of 4-thio-5-(2"-thienyl)uridine. At a low concentration of $100 \mu \mathrm{M}$, the cell survival rate dropped to around $65 \%$, then gradually declined at a slower rate along with the increase of compound concentration, finally reached the minimal value of $44 \%$ at $500 \mu \mathrm{M}$, suggesting that 4 -thio-5-(2"-

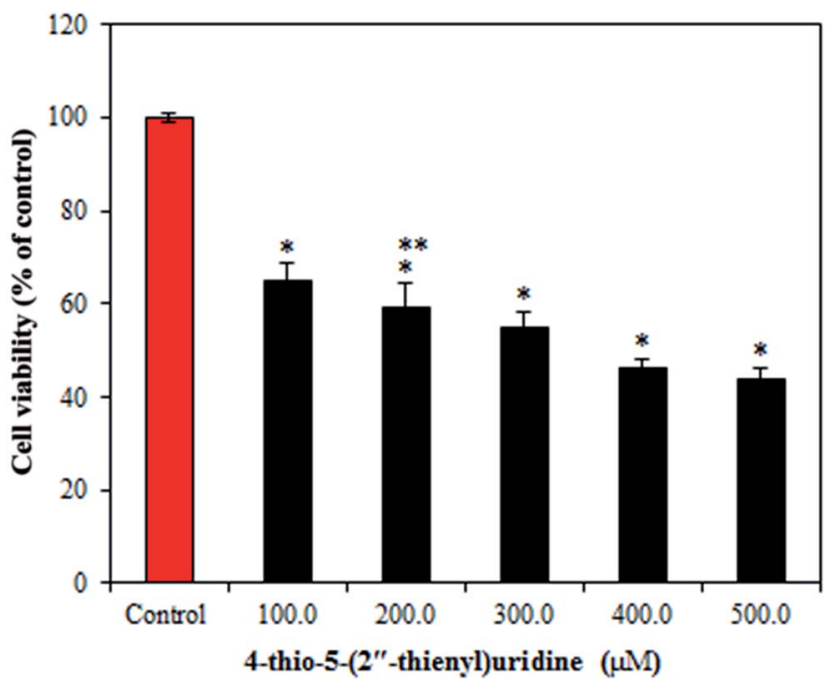

Fig. 1 Antiproliferative effect of compound 6 on MC- 38 cells. Data are expressed as mean $\pm S D$ and evaluated by analysis of variance (ANOVA). Results are representative of three replicates. *Compared with the control group, $p<0.03, * *$ compared with the adjacent lowdose groups, $p<0.05$. thienyl)uridine induced a dose-dependent proliferation inhibition of MC-38 cells. Additional increase in dosage did not further decrease the cell survival rate, and no significant cell death was detected and maintained at a relatively stable state (data not shown). The variance analysis data suggested that compound 6 had significant inhibitory influence on MC-38 cell growth $(p<0.03)$. In comparison of the adjacent low-dose groups, only the $200 \mu \mathrm{M}$ group showed significant difference $(p<0.05)$ from the adjacent groups in the inhibition of MC-38 cell growth, while no significant differences were found between the remaining groups, exhibiting a slow antiproliferative trend of the target compound along with the increase of concentrations.

3.2.2. Anti-proliferative activity against human colon cancer cells HT-29. The in vitro proliferation inhibitory activity of the prepared compounds was evaluated against the human colon cancer cell HT-29. After $48 \mathrm{~h}$ treatment under different concentrations (final concentrations: 100, 200, 300, 400, 500 $\mu \mathrm{M})$, MTT assay was adopted to examine the cell survival rate. As shown in Fig. 2, compound 6 exhibited low antiproliferative activities at $100 \mu \mathrm{M}$ level, with cell viability of $92 \%$. However, the numbers of living cells considerably decreased accompanied with the concentration increase of compound, and reached the minimal value of approximately $43 \%$ at $500 \mu \mathrm{M}$ level, suggesting that compound 6 induced dose-dependent proliferation inhibition of HT-29 cells. Subsequent increases in dosage did not further reduce the HT-29 cell survival rate, but rather maintained at a relatively stable state (data not shown). The variance analysis of the data suggested that the title compound exerted a significant antiproliferative activity against HT-29 cell from concentration of $200 \mu \mathrm{M}(p<0.001)$. In addition, the significant difference between the test and adjacent low-dose groups indicated that the inhibitory effect considerably enhanced when the compound 6 concentrations was elevated $(p<0.01)$.

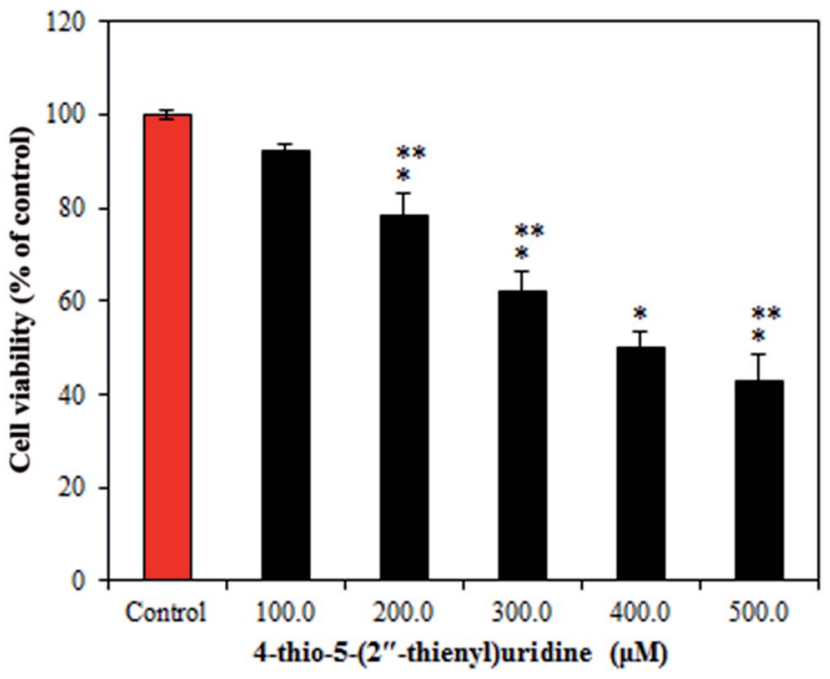

Fig. 2 Antiproliferative effect of compound 6 on HT-29 cells. Data are expressed as mean $\pm S D$ and evaluated by analysis of variance (ANOVA). Results are representative of three replicates. *Compared with the control group, $p<0.001,{ }^{* *}$ compared with the adjacent lowdose groups, $p<0.01$. 
3.2.3. Cell cycle distribution and apoptotic analysis using flow cytometry. To probe the antiproliferative mechanism of 4thio-5-(2"-thienyl)uridine in HT-29 cell, we extended our study on investing the effect of compound 6 on cell cycle progression. The cells were cultured with different concentrations of compound $6(0,100 \mu \mathrm{M}, 200 \mu \mathrm{M}, 300 \mu \mathrm{M}, 400 \mu \mathrm{M}$ and $500 \mu \mathrm{M})$
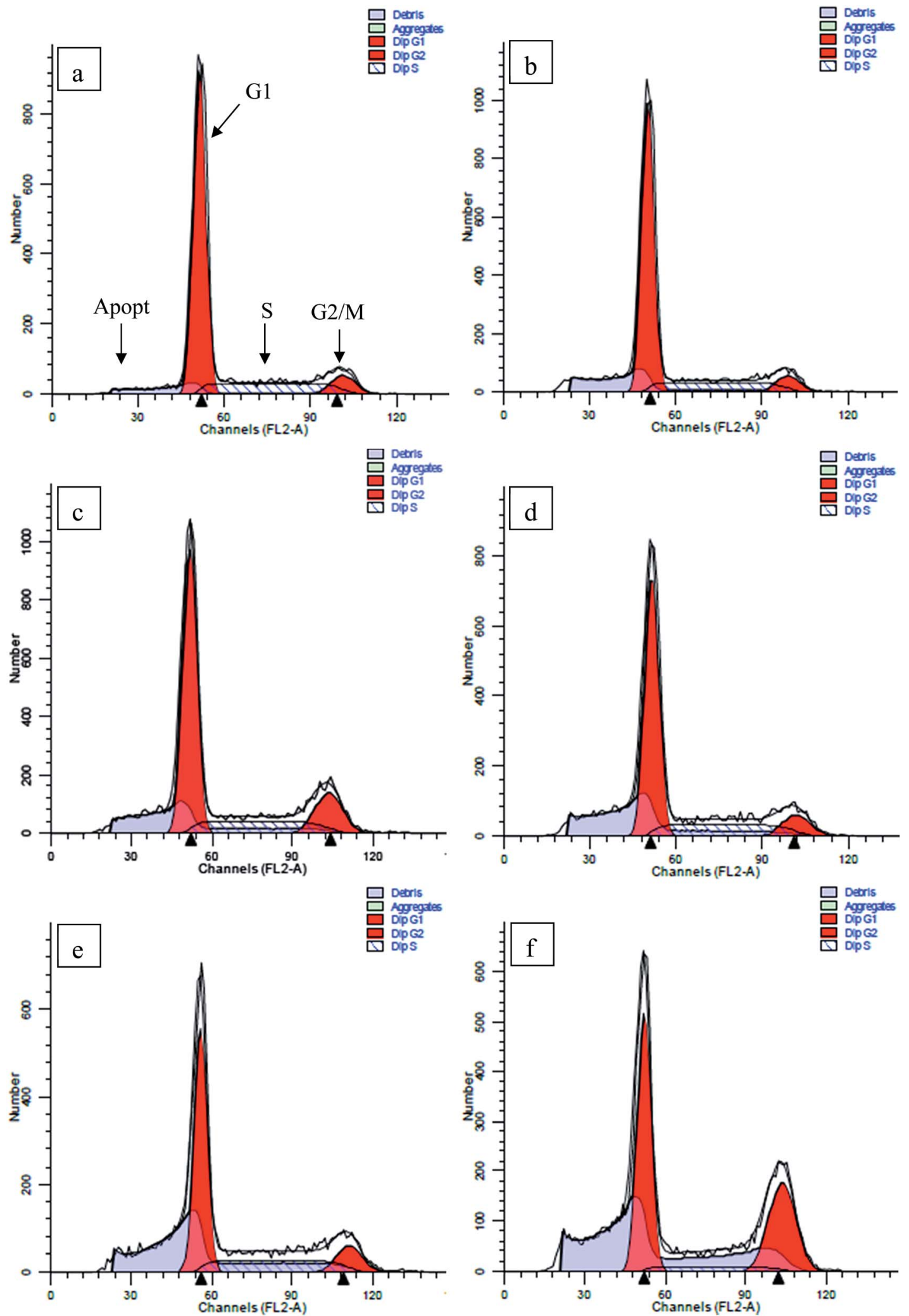

Fig. 3 Effects of different concentrations of compound 6 on cell cycle distribution of HT-29. The experiment was repeated thrice. Here only representative flow cytometric graphs are shown. 
for $24 \mathrm{~h}$, then subjected to flow cytometry to examine the cell cycle distribution. As showed in Fig. 3 and 4, low concentration $(100 \mu \mathrm{M})$ of compound 6 almost no influence on cell cycle progression, while higher concentration resulted in G2 phase and mitosis arrest in a dose-dependent manner, which reflected by the population of cells in the G2/M phase increasing from $10.85 \%$ at $200 \mu \mathrm{M}$ to $36.76 \%$ at $500 \mu \mathrm{M}$. On the other hand, there was no significant impact of compound 6 on the numbers of cells at G1 phase and S phase. Since the cells in G2/M phase had completed DNA replication (containing 4N DNA) and entered the mitosis process, the accumulation of cells at this stage implied that compound 6 plays an important role in mitotic arrest.

In addition, a fraction of cell population with DNA content lower than that of G1 (sub-G1 phase) gradually increased after exposure to compound 6 , from $10.3 \%$ (control group) to $20.54 \%$ $(100 \mu \mathrm{M}), 21.197 \%(200 \mu \mathrm{M}), 31.47 \%(300 \mu \mathrm{M}), 40.46 \%(400$ $\mu \mathrm{M})$, and $44.63 \%(500 \mu \mathrm{M})$, respectively. As the DNA replication had not yet occurred at G1 phase, the total DNA content lower than the value in G1 phase indicated the occurrence of DNA degradation in the cell, which commonly was considered as an important feature of cell apoptosis. ${ }^{20,21}$ Therefore, the increase of cell numbers at the sub-G1 phase revealed that compound 6 could induce apoptosis of HT-29 cell at such low concentration of $100 \mu \mathrm{M}$. Meanwhile, the population of apoptotic cells elevated under higher concentration, suggesting the apoptosis induction occurred in a dose-dependent manner. These results indicated that cell cycle arrest in the G2/M stage and apoptosis induction was important factors by which compound 6 exerted its inhibitory effects on HT-29 cells.

3.2.4. Anti-proliferative activity against normal human fibroblasts. The ideal anti-cancer drug should target tumors specifically while causing minimal side effects. The impact of the drug on normal cell proliferation was one of the key checkpoints in determining its specific anti-tumor activity and

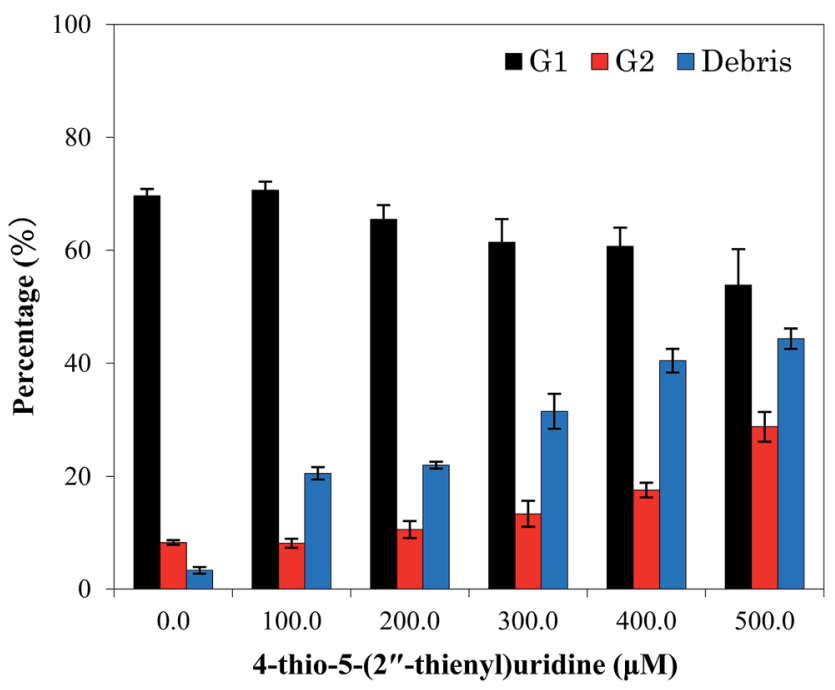

Fig. 4 Quantitative data of cell cycle analysis of HT-29 treated with different concentrations of compound 6 for 24 h. Each value represents the mean \pm SD of three independent experiments.

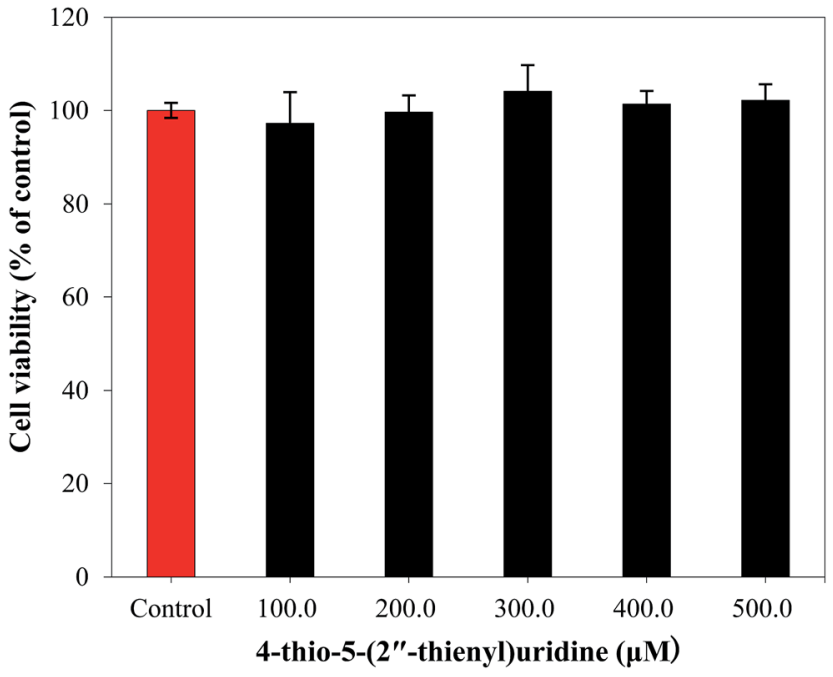

Fig. 5 Sensitivity of normal human fibroblasts cells to compound 6 . Each value represents the mean \pm SD of three independent experiments.

side effect profile. Therefore, we extended our study on examining the effects of different concentrations of compound 6 on the proliferation of fibroblast cells. After 48 hours of drug treatment under different concentrations, MTT was added to the fibroblast cells. The OD values were measured and the cell proliferation rates were calculated. The results obtained revealed that the sensitivity of normal human fibroblast cells to compound 6 were lower than that of tumor cells, and higher concentration gave no influence on cell proliferation (Fig. 5), indicating that 4 -thio-5-(2"-thienyl)uridine is a promising agent with specific anti-tumor effect.

\section{Conclusions}

In this study, we successfully synthesized a novel compound: 4thio-5-(2"-thienyl)uridine (6) by connecting thiophene to 5position of thiopyrimidine. In vitro pharmacological analysis demonstrated the compound 6 exerted proliferation inhibitory activity against MC-38 and HT-29 cells by arresting cell cycle at the $\mathrm{G} 2 / \mathrm{M}$ phase and inducing apoptosis in a dose-dependent manner. The sensitivity of the normal human fibroblasts to compound 6 was found to be substantially lower than that of the tumor cells and different concentrations showed no significant inhibition of normal fibroblast proliferation, suggesting that 4-thio-5-(2"-thienyl)uridine (6) and its analogues would be promising candidates for anti-tumor drug development.

\section{Acknowledgements}

The work was supported by the Dalian government's sciencetechnology plan projects (Grant No. 2014E12SF074), the public welfare foundation project of science enterprise investigation in Liaoning province of china (2015001024), the Dalian Jinzhou New Area government's science-technology plan 
projects (Grant No. KJCX-ZTPY-2014-0009) and Liaoning Province Education Administration (Grant No. L2013472).

\section{Notes and references}

1 I. V. Kutyavin, R. L. Rhinehart, E. A. Lukhtanov, V. V. Gorn, R. B. Meyer and H. B. Gamper, Biochemistry, 1996, 35, 11170.

2 A. M. Sismour and S. A. Benner, Nucleic Acids Res., 2005, 33, 5640.

3 S. C. Nigmn, G. S. Sahara and H. R. Shamm, J. Indian Chem. Soc., 1983, 60, 583.

4 A. B. Sen and R. N. Kapoor, J. Indian Chem. Soc., 1973, 50, 486.

5 A. G. Lezius and K. H. Scheit, Eur. J. Biochem., 1967, 3, 85.

6 M. Sprinzl, K. H. Scheit and F. Cramer, Eur. J. Biochem., 1973, 34, 306.

7 R. S. Coleman and E. A. Kesicki, J. Am. Chem. Soc., 1994, 116, 11636.

8 B. Bertoša, M. Aleksić, G. Karminiski-Zamola and S. Tomić, Int. J. Pharm., 2010, 394, 106.

9 Y. M. Lin, Y. Zhou, M. T. Flavin, L. M. Zhou, W. Nie and F. C. Chen, Bioorg. Med. Chem., 2002, 10, 2795.

10 H. M. Gabar and M. C. Bagley, Eur. J. Chem., 2011, 2, 214.

11 Y. Tang, J. Zhang, S. Zhang, R. Geng and C. Zhou, Chin. J. Chem., 2012, 30, 1831.
12 Y. Tang, Master thesis, Southwest University, Chongqing, P.R. China, 2012.

13 National Comprehensive Cancer Network, NCCN clinical practice guidelines in oncology, colon cancer, V3, 2013.

14 J. K. Stille, Angew. Chem., Int. Ed. Engl., 1986, 25, 508.

15 P. Wigerinck, L. Kerremans, P. Claes, R. Snoeck, P. Maudgal, E. De Clercq and P. Herdewijn, J. Med. Chem., 1993, 36, 538.

16 A. J. Gutierrez, T. J. Terhorst, M. D. Matteucci and B. C. Froehler, J. Am. Chem. Soc., 1994, 116, 5540.

17 R. Benhida, F. Lecubin, J. L. Fourrey, L. R. Castellanos and L. Quintero, Tetrahedron Lett., 1999, 40, 5701.

18 Y. Z. Xu, X. H. Zhang, H. C. Wu, A. Massey and P. Karran, ACS Med. Chem. Lett., 2004, 14, 995.

19 X. H. Zhang, H. Y. Yin, G. Trigiante, R. Brem, P. Karran, M. B. Pitak and Y. Z. Xu, Chem. Lett., 2015, 44, 147.

20 M. A. Lagarkova, O. V. Iarovaia and S. V. Razin, J. Biol. Chem., 1995, 270, 20239.

21 S. Nagata, H. Nagase, K. Kawane, N. Mukae and H. Fukuyama, Cell Death Differ., 2003, 10, 108.

22 K. H. Scheit, Chem. Ber., 1968, 101, 1141.

23 P. Pozarowski and Z. Darzynkiewicz, Checkpoint Controls and Cancer: Activation and Regulation Protocols, 2004, vol. 2, pp. 301-311. 